\title{
Healthy, safe and responsible: the modern female traveller
}

\author{
Irmgard L. Bauer(D)
}

\begin{abstract}
One-half of all travellers are women; yet, there is a distinct lack of detailed travel health knowledge on topics of unique relevance to women. While there is medical advice relating to stages in the female lifecycle, it neglects women-specific practical aspects despite their ability to harm travellers' health and cause inconvenience. This paper discusses comprehensively three major aspects of travel as they relate to women. First, it suggests the management of personal hygiene, bodily functions, menstruation and sexual behaviour, and alerts to the limited knowledge on travel mental health issues.

Second, apart from travelling in a female body with its specific demands, being a woman requires special attention to safety and security. Within various travel contexts, women have many opportunities for minimising potential risks.

Finally, guided by travel medicine's acknowledgment of its role in the concept of responsible travel, this article goes beyond the usual general statements and broad advice and offers detailed and practical suggestions on how the female traveller can contribute to the overall goal of minimising any potential harm to fellow humans and the natural environment. Recognising the scarcity of women-specific travel information, pathways to better education, and a range of suggestions for urgent research facilitate the provision of high-quality travel health care tailored specifically to women's needs.
\end{abstract}

Keywords: Women travellers, Travel health advice, Female hygiene, Menstruation suppression, Tourist behaviour, Risk perception

'There is no reason why a woman cannot go wherever a man goes, and further'

(Harriet Chalmers Adams, explorer, 1920)

\section{Introduction}

Historically, travel and exploration have been a male pursuit. However, since times immemorial, women also travelled, as a family or group member or a spouse. Women travels seem to have increased with the discovery, conquest, exploration and colonisation of other

\section{Correspondence: Irmgard.Bauer@jcu.edu.au}

College of Healthcare Sciences, Division of Tropical Health and Medicine, James Cook University, Townsville, QLD 4811, Australia continents when women accompanied their menfolk. Records show that, for centuries, women also travelled solo $[1,2]$ for pleasure, studies and explorations - with enormous luggage and servants - to exciting destinations, many of which are inaccessible to the modern traveller. It is not known what advice was given to historical female travellers, but in 1889 a book with hints for the lady traveller catered for the growing number of women on the move [3]. Today, the 'Recommendations for the Practice of Travel Medicine' issued by the Faculty of Travel Medicine, Royal College of Physicians and Surgeons Glasgow (FTM RCPSG), Section 16 'Travel health issues for women' [4], list a number of standards.

This paper considers women's travel from three different but interconnected aspects. First, it discusses medical

(c) The Author(s). 2021 Open Access This article is licensed under a Creative Commons Attribution 4.0 International License, which permits use, sharing, adaptation, distribution and reproduction in any medium or format, as long as you give appropriate credit to the original author(s) and the source, provide a link to the Creative Commons licence, and indicate if changes were made. The images or other third party material in this article are included in the article's Creative Commons licence, unless indicated otherwise in a credit line to the material. If material is not included in the article's Creative Commons licence and your intended use is not permitted by statutory regulation or exceeds the permitted use, you will need to obtain permission directly from the copyright holder. To view a copy of this licence, visit http://creativecommons.org/licenses/by/4.0/ The Creative Commons Public Domain Dedication waiver (http://creativecommons.org/publicdomain/zero/1.0/) applies to the data made available in this article, unless otherwise stated in a credit line to the data. 
and health issues relating to those standards and offers corresponding practical suggestions. It then moves on to the increasingly important topic of safety and security including recent developments in cybercrime. Finally, no comprehensive contemporary exploration of travel aspects is complete without the application of mindful and responsible travel behaviour, here specifically of women, to minimise harm to fellow humans and the natural environment.

The following discussion applies to women travelling solo, in pairs or groups, with men, with a life partner, as an accompanying spouse/mother of a family, or visiting friends and family. Included are women who travel for work and those whose work is travel, e.g. flight attendants, as well as women from different cultural backgrounds. It will be self-evident which aspects apply to which type of traveller, situation or destination. Much may be of no relevance for the seasoned traveller, or the woman travelling to a modern city staying in a quality hotel for shopping and visiting art galleries or the theatre, or spending a few days on a luxury cruiser. Many of the discussed issues, however, will be of great importance to novice travellers and those who leave for trips to less developed, rural, remote or wilderness regions, including unpredictable transport options, plan to volunteer short or long term in rudimentary circumstances, or rely on homestays with poorer local residents.

\section{Method}

The literature was searched using PubMed, Scopus, Web of Science, ScienceDirect, ProQuest, Google Scholar as well as grey literature and relevant websites with search terms:" female travel"", "women travel"", 'pregnancy AND travel', 'contraception AND travel', 'menstruation', 'menstruation AND travel', "menstruation suppression", "female hygiene", "urinary tract infect", 'menopause AND travel', "female sex tour", "risk perception", 'risk perception AND travel', "solo travel"", "travel safety", "travel security", 'travel AND tattoo', "pubic hair removal", 'cybercrime AND romance', "human trafficking", "touris* death". Reference lists of obtained papers yielded further sources.

\section{Health and hygiene}

General travel health advice is not discussed here apart from the comment that nuances in female biology may need to be considered more in travel medicine research as in medicine generally.

\section{Women specific travel medical advice}

Women specific considerations usually cover aspects of the female lifecycle. A summarised overview precedes the larger part of this section, the practical issues female travellers face.
Contraception Women using contraception should consider re-evaluating their method for an upcoming trip, especially if it takes them across several time zones or to unfamiliar environments, e.g. high altitude [5] and different activities. Contraception is rarely mentioned in consults even though a change to another of the many available methods may be appropriate. The combined oral contraceptive pill requires disciplined usage which can be under-mined by travel-related disruptions, or vomiting and diarrhoea. In addition, the venous thromboembolism risk increases [6]. Calculating late or missed dosages can be complicated when in different time zones. To avoid errors, some women take a second watch and adhere to their home schedule. Long acting reversible contraceptives may be appropriate for some trips. However, contraceptives do not protect from STIs, and condom use has to be discussed as well as emergency contraception.

The contraceptive pill is often suggested to suppress menstruation for convenience or for special occasions, such as honeymoons. However, there is still the possibility of 'spotting' (breakthrough bleeding), causing bother. Menstrual suppression has been studied in female hajj pilgrims for whom menstruation would make the performance of Umrah rituals impossible and so the entire journey prone to stress, anxiety and disappointment [7]. For obvious reasons, much research has been conducted on menstrual suppression in defence forces. Although some focused on operational benefits, i.e. the burden of menstruation on work performance, readiness and ability to deploy [8-10]. Others studied practical issues, especially hygiene challenges, in difficult environments of heat, dirt and rudimentary facilities [11] which mirror precisely the challenges travellers face in unforgiving circumstances and will be discussed later. The medicalisation of suppression is not welcome by all women [12, 13], a reluctance also reported by female soldiers. Hence, a tool was developed to measure attitudes towards menstruation and menstrual suppression $[14,15]$ within a theoretical model that places the woman in a microsystem of roles, activities and physical features (on deployment) [16]. This model applies easily to travel in rough and remote conditions.

Pregnancy Relatively few papers are available on comprehensive advice for pregnant travellers, especially those to remote or wilderness areas [17-21]. Others focus on vaccine safety [22] or yellow fever and malaria prophylaxis [23]; the complex topic of the latter has been highlighted in a recent editorial [24]. Further discussions deal with air travel during pregnancy [25], venous thromboembolism [26], schistosomiasis in pregnant travellers [27], anti-helminthic treatments [28], or the potential exposure to rubella during a flight [29]. More 
recently, concerns about the Zika virus added another dimension [30, 31]. Cooperation with the pregnant traveller's obstetrician is customary, also in relation to (un) planned deliveries abroad, breastfeeding and travel medications, as well as the reminder to contact the appropriate authorities in relation to a newborn's nationality.

Menopause Post-menopausal women travellers are not much considered in the literature. In a 1962 paper on aging and space, female space travellers were said to be lucky as they did not have to worry about menstruation, hygiene products, iron loss or radiation-induced genetic defects [32]. Back on earth, the recently introduced 'genitourinary syndrome of menopause' is relevant to older travellers as they need to ensure enough treatment provisions for the trip [33] as well as sufficient incontinence pads or underwear if required. Older (solo) travellers also need counsel on sexual behaviour, STIs and the use of condoms in preparation of unplanned and 'out of character' sexual activities with locals or other travellers [34].

Other issues Surprisingly rare (or unreported) severe perineal injuries due to aeroplane vacuum toilets may increase in the future with toilets getting smaller, and not only overweight or obese passengers occlude the toilet creating suction [35, 36]. A device to urinate standing may be advised but a mandatory warning should avoid more injuries. With some airlines reducing the size of the actual toilet cabinet, remaining seated on the toilet while combing hair or fixing the make-up may be the only way to manage the diminishing space.

\section{Female traveller specific practical issues}

A core concern for the travelling woman is the maintenance of her personal hygiene. This concern applies not so much to destinations in the industrialised world where facilities allow women to function like at home but to places that make a tried and tested routine difficult or impossible. However, a comfortable situation can change quickly, as has been seen in the sudden quarantines on luxury liners at the beginning of the COVID crisis, presumably with insufficient supplies.

Personal hygiene Regular handwashing or sanitizing, and maintaining a clean body should be standard routine to protect oneself and others from infections. Often overlooked is cleanliness when travelling with contact lenses. Suggestions on hygienic contact lens use to avoid serious infections can be found elsewhere [37, 38]; a habit of using up old makeup and mascara while travelling may prove detrimental. Apart from general cleanliness, intimate hygiene is of particular interest to avoid genitourinary infections, expressly when facing unusual or difficult circumstances, more so in hot and humid climates. To maintain a healthy vulvar skin microenvironment, hypoallergenic, soap-free, $\mathrm{pH}$ friendly, non-irritant female intimate washes protect against dryness often caused by soap and balance the microflora [39]. These products are available as liquids or practical wipes. Travellers should refrain from trying out harsh local culturally based cleansing procedures. Cotton underwear is often advocated to stay fresh and dry. When sweat runs down the body and pools in underwear, cotton does absorb the moisture, but then retains it and maintains a wet environment - the exact opposite of what is required. The same happens in cold, wet situations where cotton underwear and thick jeans stay wet and cold for prolonged times, possibly contributing to the development of cystitis. Moisture wicking material may be a better choice. Superfine merino underwear with panty liners have been worn with great success (observed in trekkers, IB).

Panty liners are popular to 'stay fresh' and keep underwear clean. However, they can change the microclimate and promote bacterial and fungal growth. Conventional liners with plastic back sheets increase the skin temperature, moisture and skin $\mathrm{pH}$ significantly, and 'breathable' (= vapour-permeable) or acidified products are preferable [40-42]. Sharp edges on liners may cause microabrasions and increase the risk of infection. Perfume and the disinfectant $\mathrm{Cu}$ (II)-acetyl acetonate were linked to contact urticaria and dermatitis [43].

Urogenital (e.g. urinary tract, vulvar, internal genital) myiasis has been observed due to rudimentary sanitation and poor genital hygiene [44]. Female flies are attracted by malodorous discharge, e.g. urine or menstrual blood. The female Cordylobia anthropophaga (African tumbu fly) lays eggs on clothing hung to dry, Wohlfahrtia spp. on clothing on the ground $[45,46]$. Long-term travellers and volunteers in endemic areas should be advised to iron towels and clothing, including underwear, on both sides. Less dramatic are possible candidiasis infections, especially in women on contraceptives or antibiotics, for which appropriate topical treatment should be packed.

Bodily functions Fear of embarrassment or compromised modesty, depending on the traveller's cultural background, as well as an actual or imagined lack of privacy or questionable cleanliness may make using toilets very stressful. Toilets with missing or not closing/ locking doors, holes in cubicle walls, very small cubicles, wet sticky floors, long-accumulated dirt, lacking hooks for bags or clothing, missing lights, and so on - none of this an issue for the urinating man - need to be managed. Squatting toilets are hard on hips and knees, especially for older women lacking muscle strength or with arthritis, or for those keeping their backpacks strapped 
on for lack of (dry) space, similar to female soldiers in full combat gear [47]. A small headlamp for dark toilets or for outdoors at night is useful and preferable to a torch.

A number of gadgets allow women to urinate while standing to avoid touching unsavoury toilets, or for lack of protective undergrowth outdoors. Standing upright with the men in front of perplexed locals requires considerable self-esteem, but the gadgets are very useful in dirty toilets, also on local trains, to avoid contacting anything and to keep skirts or pants off a wet floor. Any devices should be practised beforehand. Lacking men's option to urinate against a tree or a wall while clutching their luggage, solo travellers face the additional problem of having to leave bags unattended to use a toilet in an airport or bus stop. In extreme circumstances, for example, a long bus trip with no known stop useable for women, or for women who need to urinate often, wearing incontinence underwear as a temporary portable toilet can be useful. Urinating (and defecating) in challenging situations such as climbing expeditions [48] or in cold, wet, muddy, dark, overt circumstances should be planned, mentally prepared for (and practised) in advance. Best is to accept the challenge and ask others who are in the same situation - to look away. That toilets play an important part in travel show volumes such as 'How to shit around the world' [49] with plenty of anecdotes, hints and tips on the ever popular topic of elimination.

In order to minimise the need for toilets, many travellers, as do military women [50], try to limit the intake of fluids and also 'hold on' until a more acceptable opportunity arises. Though understandable, such 'prevention', possibly combined with compromised hygiene, can lead to urinary tract infections (UTIs). There is still a lack of research on fever in the returned female traveller. A small study reports upper UTIs as the leading cause of fever among women returning from the tropics, possibly due to hot climate, long journeys, dehydration and poor hygienic conditions [51]. Urinating 'just in case' whenever possible is preferable to 'holding on' [50]. The use of self-diagnosis kits for genitourinary infections in military women has been tested [52] which might be useful also for long-term travellers, as could be the currently in development smart-phone based test to identify UTIs [53].

Menstruation Menstruation is not a medical condition but can turn into a major nuisance when travelling. Travel can make periods lighter or heavier, longer or shorter, more unpredictable or disappear altogether due to stress, disturbed circadian rhythm, e.g. in female flight attendants [54, 55], or changes in climate and activities, e.g. in backpackers [56] or volunteers [57]. Women's attitude to menstruation may determine their coping abilities. For example, negative menarcheal experiences may be linked to negative menstrual attitude later in life [58]. No research on menstruating travellers appears available to-date but tools such as the long-used Menstrual Attitude Questionnaire (MAC) [59] or the Military Women's Attitude Towards Menstruation and Menstrual Suppression scale (MWATMS) [14] would be useful as travellers with more negative attitudes may support menstrual suppression for a trip. Menstrual suppression is considered frequently by travellers; however, with the practical inconvenience already discussed, it may be hardly worth the bother as sanitary products still have to be carried just in case. The relaxed approach of not using any sanitary products, as documented during a solo-crossing of Australia [60], is hardly applicable to regular travellers.

Four different sanitary products assist with menstrual hygiene. In contrast to home, many challenges can influence a normally straightforward procedure. Panty liners are often used before, after or during lighter periods. Disposable sanitary pads come in various shapes, sizes and absorption capacities to collect discharge. Sporadic research examined the presence of dioxin for bleaching fluff pulp in pads [61], the unpleasantness of pad surfaces, e.g. the wicking properties of mesh vs non-woven, and the reflux of discharge to the surface [62], an issue of interest to travellers, or dermatitis caused by pads [63, 64]. Tampons with or without applicator have been popular for a long time. A study on dioxin content was reassuring [65]. The serious toxic shock syndrome is now very rare [66] but care should still be taken to watch for symptoms, especially when far away from medical care. Menstrual cups have slowly gained popularity as a cost-effective reusable alternative which needs emptying, rinsing and re-inserting every $4-8 \mathrm{~h}$. One can even get cups with an app to monitor proceedings in the device [67]. The benefit of disposable cups [68] is less evident. Menstrual cup insertion needs to be practised for a few cycles before travelling. A systematic review and meta-analysis reported leakage similar or less compared to other methods but also some negative outcomes [69]. An incorrectly placed cup may be irretrievable without assistance [70], a potential worry on the road.

Menstrual hygiene becomes a challenge when toilets are deemed unusable, the start of periods is unpredictable or the flow unexpectedly heavy. Potential 'accidents', i.e. bleeding through clothes is embarrassing, especially when remedial action is hours away. To prepare, many women use the largest sanitary pad combined with the largest tampon. However, the more blood accumulates, the more it provides a medium for bacteria to grow and produce odour over time [50]. The same 
occurs when a tampon is forgotten, and a second one is inserted by mistake (or to 'double-up' to avoid an accident) and an alarming foul odour alerts to the problem. The feat of a soldier changing a tampon in a driving tank [47] is admirable but not the action of choice for a traveller, e.g. in an overnight bus. Pads stick poorly in heat and sweat and so may cause leakages. Changing menstrual cups in grubby toilets may lead to spillage over hands, clothes or the floor; a small water bottle needs to be carried to rinse the cup. The lack of hand-washing facilities when changing sanitary products, especially tampons, has been identified [47, 71]. Wipes may be a quick solution but running water and soap deal best with blood-stained sticky hands. Many women like to keep their periods secret and are embarrassed by dealing with changing and disposing of products, or drying bloodstained underwear in hotel bathrooms or on clothes lines between tents. Recent reports on the visibility of sanitary products on Transport Safety Administration (TSA) full body scanners at airports and subsequent upsetting treatment of the 'suspects' [72, 73] needs more clarification than a statement by the TSA [72]. The official TSA website (www.tsa.gov) does not seem to offer this. On a practical note, ideally, keeping all supplies in a bum bag (preferable to a transparent Ziploc bag), such as sanitary products, toilet paper, hand wipes, female wipes, soap leaves or mini bottle of liquid soap, and a few sanitary disposal bags to separate used and unused items, allows easy access. On the road, and to be prepared for an unintentional separation from the luggage, e.g. an evacuation from an overnight bus due to a landslide, it is best to keep supplies on the body. Despite a study on polar bears' interest in menstrual odours [74], there is no evidence that sharks and other predatory animals are keen on menstrual blood.

Sexual behaviour Many women have sex during travels with fellow travellers or local partners. The literature seems only mildly interested in sex among travellers; on the other hand, much has been written about female travellers' sex with local partners, a phenomenon long in existence but only more recently acknowledged [2]. Being away from home gives some women an unexpected feeling of freedom which allows them 'the unthinkable' adventure with a local partner, leading perhaps to an instant romantic episode [75]. Others travel for the specific purpose of having sex with locals, even considering a 'brown baby' as a souvenir [2]. In both situations, alcohol and drugs may lead to imprudent decision-making regarding safe sex but also compromise a traveller's safety and security. Travel health advice includes discussions on the importance of condom use and strategies after unsafe sex.
Psychological travel health Mental health issues in travel are woefully under-researched. Psychological wellbeing applies to any aspect of travel; only few have been discussed in the literature, none is examined in-depth, with gender a decisive but overlooked factor. More work has been conducted on long-term travellers, e.g. expatriates or volunteers, mainly on men. Women often rate a mention as accompanying spouse or mother whose feelings of boredom, isolation, alienation for not fitting into the host country's concept of the ideal woman, are acknowledged anecdotally. Having to tolerate a husband's adjustment to local requirements of heavy drinking after work and sexual indiscretions [76], or being unable to work despite being highly qualified, may lead to depression or anxiety, blaming country and people for all ills. Not coping well with (sometimes unwanted) changes of relocation, marital disharmony or reproductive concerns may make an overseas deployment torture for all involved. Younger volunteers may lose their initial sense for adventure when homesickness sets in, the famous culture shock, or difficulties with the practicalities of life, such as hygiene, food, lack of privacy during homestays including relaxed local attitudes towards ectoparasites [77]. The need for pre-travel mental assessment and post-travel debriefing has been highlighted before [78, 79] but not all problems can be foreseen. Difficulties in readjusting to life back home, a 'reverse' culture shock, and the realisation that people at home are not that interested in one's overseas experiences, nor are potential employers, are distressing for many returning women.

Leisure travellers may also experience distress and anxiety. Mental health issues in air passengers and crew [80] and especially a fear of flying [81, 82] have been discussed, the latter suggesting a higher prevalence in women, although there seems to be no more recent evidence. On the ground, distressing worries about privacy and hygiene but also culture shock, homesickness, loneliness and unfamiliar or frightening ways of going about daily lives may trouble some women while others thrive on these challenges. For obese travellers, shame, humiliation and embarrassment for the inability to do simple travel-related activities, especially evident in air, train or bus travels, or for not displaying a pleasing body shape can ruin an otherwise enjoyable trip [83]. For some travellers with psychiatric problems, repatriation may be necessary [84]. On the other hand, travel can do much for mental wellbeing, either by enjoying sights and sounds of a destination, a particular mode of transportation, or by feeling a sense of achievement after completing a particular feat or to balance out a personally difficult time. Women travelling for a sport event displayed improved wellbeing [85]. Links between risk-taking and personality traits have been suggested [86] including their application to travel risk perception [87]. Apart from cultural 
differences [88], gender influenced travel risk perceptions and subsequent international travel intentions [89]. Unsurprisingly, for many women, the need to be particularly weary about their personal safety, a topic discussed next, may have them travelling constantly on edge to the point that enjoyment is replaced by fearing the worst.

Traditionally, and originating in the West, travel medicine has catered for the Western tourist. This focus has expanded recently with the inclusion of migrant health but it seems not yet to consider VFR travellers from developing countries visiting emigrant family members and friends in Western countries. These women may differ in skin colour, facial features and dress, and may be mistaken for immigrants and asylum seekers. Veiled and non-veiled tourists in industrialised countries suffer a reversed (not reverse) culture shock at destination [90]. Immigrant and religious stigmatisation [91] spoils their tourist identity [92], leaving the women with feelings of injustice, shame, insecurity and the desire to go home.

\section{Safety and security}

Centuries ago, immediate danger threatened from unsafe roads, inclement nature, untrustworthy modes of transportation, unsavoury fellow-travellers, wild animals and hostile 'natives'. Many women will have met with misfortune but many others have returned home to tell the tale. With increasing female education and literacy over the last centuries, women's travel literature, especially of the 19th and the beginning of the 20th centuries, testifies to the often dangerous episodes and how the women overcame them. Today, there are contemporary versions, which equally need to be addressed. This section focuses on the FTM RCPSG standard 'personal security' [4] and presents aspects of women's travel safety and security, suggesting ways to minimise potential risk. Safety generally means protection against unintended threat while security protects against deliberate harm. This paper does not distinguish, as carelessness in one can jeopardise the other, and many overlaps exist.

\section{Protection from unintentional harm}

Safeguarding one's health goes beyond clean food and water. Enthusiastic travellers often return home sporting a temporary souvenir, such as braided or beaded hair or red henna decorated hands. A rare case of contact dermatitis has been reported after a temporary black henna tattoo due to added para-phenylenediamine [93]. Perhaps in an altered state of mind, obtaining a permanent tattoo or a piercing in a local salon with unknown safety standards seems a good idea but exposes the traveller to a range of surface or systemic infections including sepsis or HIV. The current trend of pubic hair removal at home, or as an exciting novelty on destination, may expose women not only to infections due to microabrasions, microtears or burns during the procedure - and delayed healing in hot and humid climates - but also to STIs [94-97]. Pubic lice infestations, however, may decrease [98]. Other selfinflicted risks occur when trying out substances such as mescalin or ayahuasca [99] or suffering methanol poisoning after sampling cheap local alcohol [100].

\section{Protection from intentional harm}

The main concern, however, is being subjected to harm by others. In most places, travellers are easy targets for their skin colour, casual clothes, and tourist gadgets. They also have to deal with the 'stigma by association' [91] which links them to the behaviour of female tourists who visited before them. Solo travellers may feel particularly vulnerable [101]. Women have travelled solo for a long time - and written about it [102]. The social construct of womanhood with a set of standards of femininity in the late 18th and the 19th centuries [103] did not include women taking off on their own, imitating men, and getting in harm's way. Only more recently was the transgression into the male domain of (dangerous) adventure tourism challenged by women [104]. Today, travelling solo is still difficult for many women. In a Norwegian study, the majority of female university students found solo travelling frightening [105]. Australian women revealed four categories of constraints to solo travel - pre-travel and on location: socio-cultural, personal, practical and spatial [1]. Their fears were: others' perceptions of them, being prone to vulnerability in unknown spaces, having a sense of restricted access and temporal mobility, as well as the feeling of conspicuousness, i.e. proneness to the male gaze [106]. Very recent papers focus on the Asian solo traveller, an increasing market segment, reporting fear and vulnerability [107], gendered risk (from wolf whistling, stalking, groping to rape), racialised risk (outside Asia), and being mistaken in Asia for local sex-workers, as Asian women are not supposed to travel alone [108]. India was singled out as a place to avoid $[109,110]$, especially after much publicised rapes [111]. This fear is not unfounded with nonpartner violence common around the world [112] and tourist hotspots providing unwelcome happenstances [113]. Even in-flight sexual assaults have been reported [114]. Danger to life and limb is real as sporadic media reports of missing or murdered travellers highlight. Travelling solo makes some women more vulnerable in certain circumstances but they are also found to be often much more careful by avoiding dangerous situations. Women travelling with one or more females for the purpose of 'having fun' and 'having each other's back' may engage in riskier behaviour due to a false sense of protection from the others. 
Travellers' risk perception usually sees the traveller as the victim of adversity [115]. Scales have been used to predict risk behaviour [116]. However, much happens during travel 'out of character'. Conscious risk-taking is not well researched, for example, why some women accept or actively seek high risk during travel. Being in a liminoid time-space is an explanation for bad behaviour, not an excuse. Physical and sexual attacks are the biggest danger for any women, solo or otherwise. Appropriate behaviour can minimise the risks. Being realistic and stating the obvious is not always welcome in the current climate. The popular statement 'it is never a woman's fault' is unhelpful as, at home and away, it absolves women from the responsibility of making prudent choices, including maintaining mental alertness, undulled by substances.

Women can take many precautions to travel safely. In preparation of the trip it is important to understand the destination (culture, standards) as well as oneself. Introspection should uncover any traits that might lead to unwise decisions. The trip's purpose should align with the preparation, and information always left with friends and family at home. 'What if...?'-scenarios need to be planned, e.g. adverse events, sudden dangerous situations, and so on. Several operators offer young single women the opportunity to accompany rich men on luxury travels for free. These arrangements are not free. Anxious or inexperienced travellers may feel safer with female-only operators.

General statements of 'taking care' or 'being careful' are not helpful; more specific hints usually are, especially for women who normally live in safe and protected circumstances. The following few key areas are supported by selected suggestions in Tables 1, 2, 3 and 4 . Not all these hints apply everywhere and at all times; not every woman will need all or any. Women cautious at home will implement them by default; novices should take note. Planning transport and accommodation at least for the first days safeguard the start in an unfamiliar environment. Precautions for accommodation depend on the type of dwelling and the area in town as well as physical factors of building and surroundings (Table 1).

Appearance and behaviour are important aspects of travel, not only to show respect to the host country but as a precaution against harm. Many women claim it their right to wear whatever they like where they like and behave in whatever way they wish since they are on holidays and paid for their enjoyment. This opinion has nothing to do with personal freedom and contradicts common-sense. What body parts local women cover is a good guideline as local mores may require covered shoulders, arms, or knees. Arguing with a guide about different perceptions of when a knee is covered is embarrassing and displays a lack of understanding and respect. Table 2 lists a few suggestions.
Table 1 Transport and Accommodation

\begin{tabular}{|c|}
\hline Transport \\
\hline Avoid night travel; avoid arriving at night \\
\hline Arrange airport transfer to hotel in advance \\
\hline Use licensed taxis (know what they look like) \\
\hline Sit behind the driver \\
\hline Make 'phone call' in taxi to say you arrive shortly \\
\hline Pay taxi while still in the car \\
\hline On public transport, sit near women, use 'pink tuk tuk', lady taxis \\
\hline Self-drivers: Park so that you don't have to back out \\
\hline Accommodation \\
\hline Booking \\
\hline $\begin{array}{l}\text { Pay more for safety; avoid ground floors; choose 'women floors'; } \\
\text { avoid dorm beds or camping solo; swags restrict movement in } \\
\text { case of an attack }\end{array}$ \\
\hline Book without title Miss, Ms., Mrs \\
\hline Avoid couch surfing with a male host \\
\hline Arriving \\
\hline Check in without title \\
\hline Check phone is working, lockable door, chain at door, peephole \\
\hline Staying \\
\hline Use a rubber doorstop if necessary \\
\hline $\begin{array}{l}\text { Keys: best unmarked swipe keys; cover key room number in } \\
\text { restaurant; avoid saying room number loud at reception/restaurant }\end{array}$ \\
\hline Don't get into the elevator with a stranger \\
\hline Leaving \\
\hline Write down hotel name and address in local language \\
\hline $\begin{array}{l}\text { Leave note in hotel where you go that day (but ensure that no } \\
\text { unauthorised person hears in) }\end{array}$ \\
\hline Don't discuss in public where you are staying \\
\hline
\end{tabular}

Interpersonal safety aspects concern interactions with others (known and unknown) to minimise harm to life and limb. Prudent and cautious interactions are asked for, not paranoid reactions. Misfortune often strikes with the involvement of alcohol or drugs and the abandonment of natural instincts. In addition, inebriated female tourists losing self-control do not evoke a high opinion in locals. Women whose behaviour is interpreted as invitation or provocation, or which makes them the object of ridicule, are not safe. Table 3 presents a list of suggestions out of a great many more. Female travellers should also have a plan of what to do if they are assaulted or how to get out of an increasingly dangerous situation. Members of local authorities are not necessarily trustworthy.

The safety of one's possessions is of importance as theft or damage not only ruin a holiday but can eventually jeopardise personal security. Female travellers are often scammed by women using 'sisterhood' as a cloak. 
Table 2 Appearance and Behaviour

Appearance
Dress modestly, not provocatively
Wear pants rather than skirts (or pants/leggings under skirts)
Observe the local dress code $\rightarrow$ check what local women cover
Wear headscarf where appropriate
Consider wearing a wedding ring and carrying a photo of a fake
husband
Behaviour
Sensible Behaviour
Stay alert
Stay in well-lit, populated areas
Keep low profile; try to blend in; walk confidently, with a purpose
Enter a shop or business if there is a threat
Don't try-on clothes in bazaars, suqs, markets
Don't wear noise-cancelling earbuds or music ear buds
Conceal your map/guidebook in the street
Control your own behaviour
Communication
Make sure your mobile phone is always freshly charged
Put local police on speed dial
Stay connected as a precaution
Other
Learn a few basic phrases
Check sunthority

Table 4 presents a list of hints but women should be aware that criminals are usually one step ahead, know all precautions and change their mode of operation accordingly. Fake soiled lingerie, prominently displayed on top of backpacks or suitcases, can keep some long fingers away.

Women are now the main victims of online romance scams [117]. This crime progresses through stages [118], involves transfers of money and often travel to the country of the cyber-partner. Women then find that not only does the man not resemble that expected partner but themselves involved in criminal activities, such as money laundering or drug muling. They may be kidnapped [119], or become a victim of human trafficking, recruited by their trusted 'boyfriend' [120, 121], an occurrence even in Western countries [120, 122].

Finally, harm can be the purpose of travel. Arranged marriages (especially under-aged girls) are prone to inflict physical and psychological harm. Girls travelling for a 'special celebration' should alert a travel health consultant. Female genital mutilation (FGM) has received
Table 3 Interpersonal Safety

$$
\begin{aligned}
& \text { Plan ahead } \\
& \text { Find out gender issues and attitudes towards women at the } \\
& \text { destination } \\
& \text { What are acceptable manners? Is it appropriate to approach men for } \\
& \text { questions? Does looking into men's eyes mean an invitation? Shake } \\
& \text { hands? } \\
& \text { Do you know yourself enough? What are your plans in case ...? } \\
& \text { Could your travel plans expose you to risks? } \\
& \text { - Shamanic experiences; sexual assault linked to ceremonies } \\
& \text { - Sex/romance tourism: more problematic where women tourists } \\
& \text { are new - local men don't know how Western women function } \\
& \text { - Legal situation regarding adultery, pre-marital sex }
\end{aligned}
$$

\section{Encounters}

Don't invite visitors to your room; don't accompany men to their room; meet in foyer or in public places

Avoid using local dating apps

Don't accept rides with strangers

Understand local perception of Western women

Limit alcohol, avoid any drugs; be aware of drink spiking

Be alert at 'full-moon parties'

Be alert in crowds

Don't eat/drink somebody's food if they don't eat the same

Don't discuss travel plans with strangers

Be aware of people posing as police or tour guide

Control your own behaviour

Know procedure in case of rape (police reports, forensic examination etc)

\section{Protection}

Wear a whistle, 'rape alarm'

Carry personal protection devices if legal at destination

much greater attention in recent years, even though how to deal with the legal requirements and overcome barriers to discuss are less clear [123-125]. Some guidelines are available [126] as well as a free eModule from the FTM RCPSG [127]. FGM may not yet be part of general practitioners' perception of risk for VFR Travelers [128].

\section{Sustainable development and responsible travel}

Women's unique travel-related needs also highlight women's specific role, obligation and opportunity within the context of responsible travel beyond the general guidelines as they apply to all travellers. Historically, travel was more about consumption rather than consideration (in 1889, women were encouraged to simply throw soiled linen overboard [3]). Never before has the demand for considering the impact of one's travels, mindful and responsible behaviour, and sustainable actions been greater than today. Genuine conviction or compliance with political correctness, travel operators 
Table 4 Safety of Property

Luggage
Ensure luggage not too heavy to slow you down
Use luggage in bold colours, personalise heavily or 'uglify' to make it
easily traceable and unsellable
Use covered luggage tags; use office rather home address
Be alert in train sleepers, on bus
Theft-proof bags (steel wire in handle/strap)
Wear shoulder bags across body
Keep handbag away from street side

Documents

Plan how to carry documents and copies of your passport, visa, prescriptions, ticket

Don't make copies of your credit card; memorise details

Keep your identity safe

Avoid cargo vests for carrying money and documents; they can be ripped off easily

Money

Understand money notes, coins and exchange rate beforehand Use ATMs during the day; bring enough cash for the first days

Be careful with anything where you need to get your wallet out

Use dummy wallet with little cash

Use karabiner clip wallet; sew safe pocket under bra or inside pockets in pants

Use travel 'safes' (money belt, money pouch, leg pouch etc.) but ensure none shows through clothing

\section{Stay alert}

No distraction

Secure luggage, laptop, tablets, personal information

Flashing a laptop or tablet in public may invite robbers

Don't resist when robbed; hand over valuables

Watch out

Watch out for scams targeting the female traveller (e.g. by women with babies or group of children)

Learn about current pickpocket methods and scams

are expected to demonstrate their reduction in harm caused by travel and travellers. The International Society of Travel Medicine's (ISTM) recent interest in the UNSustainable Development Goals (SDGs) [129] may lead to some alignment between the sustainability paradigm and travel medicine. While the SDGs have been written for governments and global organisations, travel clinics, travel health practitioners and travellers can play their part in contributing mindfully to the overall goals. The aim is to avoid a burden on destinations, especially fragile and vulnerable environments, and a negative impact on local lives and livelihoods.

The notion of a 'shared prosperity in a sustainable world' [130] is alluring, highlighting the two main foci: poverty and environment. Only in exceptional cases does tourism reduce poverty and so improve the health of the poor as the status quo is in the interest of many powerful stakeholders [131]. Climate change and the environment are on the forefront currently, yet, much of ecotourism is not at all 'green'. Some years ago, travel medicine touched on the concept of OneHealth [132], the health-interrelationship between people, animals and environment. The interest in people's health is obvious, in environmentally friendly travel mild, but the role of travel medicine in animal welfare is minimal [133].

Responsible travel is mindful travel turning exploitation into consideration. Destinations, especially poor countries, have no obligation to provide a playground and clean up after us. Economic, environmental, sociocultural and political impacts of tourism have been discussed from the 1960s onwards. These recognised impacts' influences on local health and wellbeing as well as tourism's direct health impacts, such as transmission of infections, accidents, and occupational health and safety, were only considered from the mid-1990s [134]. Within the ISTM in the 1990s, the then 'Host Countries Committee' (now 'Responsible Travel Group') began a fringeexistence as a curiosity; the need to care for the hosts is now accepted. This section suggests to female travellers actions that can contribute to responsible travel, careful consumption and waste disposal, and appropriate conduct, by first addressing the established overall tourism impacts and then focussing on women-specific practical aspects.

\section{Mitigating negative economic impacts}

To assist the local economy, and acknowledging that families enjoy a better standard of living when women are in employ, travellers should spend locally on accommodation, transport, food, craft (not foreign copies), and avoid aggressive haggling. Female tourists seem to buy more souvenirs than men [135]. Women can enter local homes more easily and may be able to buy directly from craftswomen. In some countries women face barriers to participating in the tourism industry [136]; elsewhere, women can benefit directly from tourism, often as small business owners. Supporting local women helps overcoming gendered disparity and cultivate women-towomen interactions, for example, in the case of female guides in Nepal [137].

\section{Mitigating negative environmental impacts}

Environmental mindfulness includes supporting local environmentally beneficial efforts, such as low carbon transport and the use of filtered water over plastic bottles. Beauty regimes can be upheld with less water, where scarce, and ecofriendly cosmetic products. Specific waste disposal will be discussed in the relevant 
sections later in this paper. Gifts should be more useful than burdensome. Donations' end-of-life disposal needs consideration: soaps and shampoo as bars in paper or cardboard instead of plastic wrappers, no plastic toothbrushes, no small hotel bottles, traditional good quality pencils instead of plastic casings, and so on. In short, polluting gifts should not turn locals into polluters.

\section{Mitigating negative socio-cultural impacts}

Female travellers have a unique opportunity to bridge cultural distance and maximise socio-cultural understanding by making friends with local women. Visiting homes (invited) and exploring local life through local women's eyes counteract perceived differences [138]. Respectful behaviour excludes aggressive promotion of Western values or patronising and ridiculing disapproval of challenging customs, such as geophagy [139] or decorative scarring. It excludes crossing the line by requesting unacceptable favours, such as breaking taboos, which create (intergenerational) family or community tensions as does singling out individuals for gifts or donations. It is better to donate to schools or health centres, for the benefit of all. Local children in 'orphanages' or local sexual partners are not playthings [140]. Purchasing souvenirs that demean local women is not responsible; female travellers have no automatic right to photograph local women without their consent. Many famous resorts around the world, e.g. Boracay in the Philippines, have been built on ancestral land after removing the indigenous population with a particular devastating impact on women and children. Researching the history of one's destination and possible rectification strategies should guide a responsible choice of one's holidays.

\section{Mitigating negative health impacts}

Following the above suggestions, female travellers safeguard indirectly local people's mental and physical wellbeing. However, their behaviour can also minimise direct risks to local health. Personal cleanliness and social etiquette, mindful disposal of waste and sanitary products and safe sex protect local hosts, whose health may be compromised due to malnutrition, parasites or infections, or limited finances to seek health care. Driving with care and other considerate behaviour avoids harming locals. Workplace health and safety regulations are often non-existent. Using 'delicate femaleness' as leverage is not responsible behaviour. Travellers should not ask for excessive services, e.g. carrying heavy backpacks [141], dangerous or illegal activities or unreasonable favours, but rather inquire about and check what operators do to protect the local workforce. It helps being aware that one's enjoyment is often only possible by exploiting a local workforce or local people.

\section{Women-specific practical aspects of responsible travel} Guidelines for responsible travel are ubiquitous but rarely go beyond general statements. Detail of how to implement those guidelines is normally missing. This section provides such detail linked to some core concerns of female travellers. The main focus is on waste disposal and on appropriate behaviour.

Personal hygiene The responsible traveller washes her hands, coughs into her elbow, sneezes into tissues, disposes mindfully of contaminated products and so assists in curbing the spread of respiratory and gastrointestinal infections to local residents. Half-empty containers of shampoo, washing liquid and so on may be happily accepted or empty containers repurposed by local women; otherwise, bottles should enter a recycling stream or be taken back to the best facility for disposal. Wipes may be able to be burned but must not be thrown into toilets or left in the outdoors (also not buried). Regular panty liners are hard to recycle and should not be discarded but carried back. Small zip lock bags can cater for such waste.

Bodily functions In many regions, local plumbing does not accommodate toilet paper which should be deposited in the provided receptacles. In the outdoors, toilet paper should be burned or carried out, never left on the ground or buried. Especially for defecation in the outdoors, there are specific rules about where and how deep a hole needs to be dug. Covering faeces with leaves or rocks attracts animals and is unsanitary, especially in the case of infectious diarrhoea. Disposable urine gel receptacles are useful in some situations but not in areas without proper disposal management. Incontinence pads and underwear should equally be carried out and dealt with responsibly.

Menstruation An innate urge to disassociate oneself from waste by stepping away quickly may make otherwise sensible women do bizarre things. Sanitary products must not be disposed of in toilets and should not add to the burden of the local waste disposal system. If fluff can be burned locally, the plastic casing needs to be removed and disposed of responsibly (by carrying out). Sanitary products should not be buried in the outdoors as animals can dig them up, tampons not flung into the bushes. The use of reusable pads and their washing and drying may be something to get used to but avoids adding to the enormous landfill, i.e. up to $26 \mathrm{~kg}$ of pads over 10 years/woman [69]. Tampons without applicator are preferred or at least those with paper applicators. Plastic applicators, popular in the US, cannot be recycled and should be carried out, similar to applicators for vaginal moisturisers or topical treatments. The recent keen 
market for used sanitary products to produce hallucinogenic drinks $[142,143]$ is of limited use to the travelling women.

The importance of menstrual hygiene products for girls and women in developing nations has attracted recent interest [144, 145]. Sanitary products are not just pieces of pulp absorbing blood. They open the door to life-changing education for girls around the world who are unable to attend school because of a culturally imposed local stigma. Managing menstrual hygiene is 'an issue of social justice within the context of public health' ([145],p. 1302). Many campaigns distribute disposable products in low-income countries (see '28 May Menstrual Hygiene Day' [146]), though their disposal is still problematic. Donating reusable pads to visited communities may be a better option [147]; local women's views on washing and drying them where menstruation is a taboo and a matter of shame and discrimination, need to be ascertained first. As always, donating without considering the end-of-life cycle of the item and the burden of disposal, is not responsible.

Sexual behaviour The responsible traveller not only protects herself from STIs but also her partners by using condoms. However, not only physical health is implicated. Local men available for tourist sex can be resented by their families and local society as they do not follow cultural script. Displays of affection in public initiated by travellers may upset community standards, and a destination can acquire an unwanted reputation. More details on local impacts of sex between female travellers and local men can be found elsewhere [2]. Contrary to common belief, not all men are romantic entrepreneurs. Some suffer mentally when their temporary girlfriends leave perhaps forever [140].

Psychological health A mentally unwell traveller affects her fellow travellers as well as local hosts. The manifestations of the problem, e.g., verbal or physical aggression, mood swings or deep sadness, can cause anguish, offense, disappointment and misunderstandings. Unfriendliness, belittling of customs, rejecting well-meaning help, criticising local lifestyle or food may be perceived as personal or cultural rejection. The way a Western woman expresses her unhappiness may be puzzling or offensive to others who themselves are then affected.

Respect The responsible traveller shows respect for the hosts in comportment and dress, especially in places of worship (churches, mosques, temples, sacred sites). Visits to Islamic countries challenge some Western women. While Muslims have a traditional obligation to offer hospitality to strangers, tourists need to abide by the rules respectfully. Islam encourages tourism but many countries do not offer clear dress codes for female tourists. While Iran and Saudi Arabia have guidelines [148], in Egypt, for example, female dress codes vary between progressive and conservative families, and resentment to scanty clothing extends to tourists, whereas in Malaysia, rules for Muslims are strict, for non-Muslims somewhat relaxed [149]. The mindful traveller also avoids eating her meals or drink in public during Ramadan. Fitting into local female norms [150] for a limited time allows a deeper insight into a destination as difference is one appeal of travel. Showing respect, female travellers will be respected back.

\section{Recommendations for education}

Experienced women have learned over time and frequently share their advice on relevant travel websites. Oftentimes, common-sense just needs some additional hints and reminders. A standard travel consultation rarely affords the time for a comprehensive discussion of topics beyond the specifically medical issues. Detailed suggestions relating to the three main areas covered here should not end up as a politically correct exercise buried in academic papers, only accessible to a limited number of readers. International travel medicine organisations, such as the ISTM and the FTM RCPSG, and regional organisations should make travel health advice more accessible to the travelling public via women's magazines, blogs, and women-specific travel sites such as Journeywoman.com. They could make available to clinics, travel health professionals and the public downloadable guidelines, which should be updated regularly. ISTM's Responsible Travel bookmarks and flyers published in the early 2000s were a useful start but, time progressing, advice needs to be updated, amended, and new developments in types of travel, tourist activities and shifting interest incorporated. Assistance should also be provided to local accommodation and hospitality as well as local tour operators so that women can be given locally relevant advice.

The problem with 'compliance' with health advice is not new [151]. The responsibility of implementing behaviour change is placed with the individual after somebody else has instructed what needs to be done. Doubting the ability of the individual to control behaviour based on causal and moral responsibility, a recent discussion included the notion of prudence into health promotion, i.e. following advice because it is in accord with people's own interest in their health and wellbeing [152]. This approach could be explored more in travel medicine.

\section{Recommendations for research}

Women specific research in travel medicine is relatively scarce; women's views on and experiences of many 
travel-related women-specific issues seem completely neglected. Much research in travel medicine and tourism focuses on travellers' attitudes, yet fails to address the highly complex nature of that concept [153] which, again, should be explored gender-specifically because it impacts on health, safety and responsible behaviour.

This article contains many potential research topics. In relation to health and hygiene, of particular interest is an insight into travel-related barriers and challenges unique to women and the degree of success in coping with them. Topics include aspects of the female lifecycle, such as contraception, menstruation (suppression), pregnancy, menopause and sexual health. Further areas are practical issues relating to personal hygiene, bodily functions and potentially yet undiscovered topics. Mental health issues are largely ignored, as are challenges for the accompanying wife or caregiver of children and other dependent family members. An understanding of women's specific expectations from travel consultations should prove useful. Some defence force research, while not necessarily transferable, may suggest further topics, also for comparison's sake.

In terms of safety and security, not enough is known about the health outcome of women-specific body alterations made during travel (excluding medical tourism). (Solo) female travellers may report particular yet unknown travel health and safety concerns and a corresponding need for inclusion into travel health consultations. More insight is required into a womenspecific association between risk perception and behaviour during travel and at destinations. While there is a large body of knowledge in tourism academia on local people's perceptions of tourist behaviour, more insight is needed into locals' perception of female travellers' safety and security.

Topics within the context of responsible travel, from a female perspective, seem completely neglected. Even recent research on sustainable travel behaviour does not differentiate between genders, a difference one might assume when it comes to towel and linen reuse in hotels $[154,155]$. This lack of evidence provides an empty canvas for numerous research topics arising from this paper. There is a lack of knowledge about women's understanding of responsible travel behaviour and their possible need for more information. A more specific focus on locals' perception of behaviour and conduct of female travellers, especially in traditional societies, present a further opportunity for collaborative investigations. Research on women-only tours and with solo travellers, in relation to responsible travel behaviour, but also safety and security, may yield unexpected insights.

Cooperation with tourism researchers should pave the way for more multidisciplinary research on topics of mutual interest [156]. Validated research methods from other disciplines can assist where topics are outside the applicability of traditional medical and positivistic protocols, for example, research on location with smartphones $[157,158]$.

\section{Conclusion}

For most women, going on a trip involves a number of medical preparations as well as careful planning of practical aspects around hygiene, yet, there is scarce discussion in travel medicine about the travelling women's needs and challenges outside traditional topics. This paper offered a long overdue presentation of three distinct but interconnected aspects of great importance to these travellers, including suggestions for education and much needed further research. First, it provided a much more detailed exploration of travel health and hygiene than usually given. However, for women, the preparation of a trip involves more than just strictly medical considerations. Safety and security are of concern when venturing outside the perceived protection of the familiar realm. The excitement of travel may lead to unwise decisions based on an altered perception of risk. Harm can be self-inflicted or inflicted by others. Not following prudent advice does not necessarily lead to misfortune but smart behaviour allows women to have a safe and enjoyable trip. A range of common, potentially unsafe situations include the more recent cybercrime. Finally, the concept of responsible travel is not new to travel medicine but its acknowledgement has rarely progressed beyond general statements and suggestions, even though questionable practices in a range of travel situations are well known. This paper presented responsible behaviour in a more detailed and practical sense, applied to women as a specific travel population. The individual female traveller cannot compensate for large-scale inaction but she has many opportunities to avoid aggravating local problems. 'Doing the right thing' may be difficult or impossible at times, but striving for it allows women to travel while safeguarding fellow humans and the natural environment.

\author{
Acknowledgements \\ Not applicable. \\ Author's contributions \\ The author(s) read and approved the final manuscript. \\ Funding \\ Not applicable. \\ Availability of data and materials \\ Not applicable.
}

\section{Declarations}

Ethics approval and consent to participate Not applicable. 


\section{Consent for publication}

Not applicable.

\section{Competing interests}

Not applicable.

Received: 4 January 2021 Accepted: 25 May 2021

Published online: 05 June 2021

\section{References}

1. Wilson E, Little D. A 'relative escape'? The impact of constraints on women who travel solo. Tour Rev Int. 2005;9(2):155-75. https://doi.org/10.3727/1 54427205774791672

2. Bauer I. Romance tourism or female sex tourism? Travel Med Infect Dis. 2014;12(1):20-8. https://doi.org/10.1016/j.tmaid.2013.09.003.

3. Campbell Davison L. Hints to lady travellers: at home and abroad. London: lliffe \& Son; 1889.

4. Chiodini J, Anderson E, Driver C, et al. Recommendations for the practice of travel medicine. Travel Med Infect Dis. 2012;10(3):109-28. https://doi.org/1 0.1016/j.tmaid.2012.05.002.

5. International Climbing and Mountaineering Federation. MEDCOM: Contraception and period control at altitude, 2010. https://www.theuiaa. org/mountaineering/contraception-and-period-control-at-altitude/. Accessed 20 Oct 2020.

6. Borwein S. Contraception in female travellers: challenges and solutions. J Travel Med. 2019;23(8):1-4. https://doi.org/10.1093/jtm/taz071.

7. Dandehbor W, Kazemi M, Shahrbabaki M, et al. Menstrual suppression using oral contraceptives by female hajj pilgrims. Int J Travel Med Glob Health. 2016:4:111-4. https://doi.org/10.21859/ijtmgh-040405

8. Christopher $L$, Miller L. Women in war: operational issues of menstruation and unintended pregnancy. Mil Med. 2007;172(1):9-16. https://doi.org/10.72 05/MILMED.172.1.9.

9. Powell-Dunford N, Cuda A, Moore J, et al. Menstrual suppression for combat operations: advantages of oral contraceptive pills. Womens Health Issues. 2011;21(1):86-91. https://doi.org/10.1016/j.whi.2010.08.006.

10. Powell-Dunford N, Cuda A, Moore J, et al. Menstrual suppression using oral contraception: survey of deployed female aviation personnel. Aviat Space Environ Med. 2009;80(11):971-5. https://doi.org/10.3357/ASEM.2566.2009.

11. Trego L. Military Women's menstrual experiences and interest in menstrual suppression during deployment. JOGNN. 2007;36(4):342-7. https://doi.org/1 0.1111/j.1552-6909.2007.00166.x.

12. Gunson J. "More natural but less normal": reconsidering medicalisation and agency through women's accounts of menstrual suppression. Soc Sci Med. 2010;71(7):1324-31. https://doi.org/10.1016/j.socscimed.2010.06.041.

13. DeMaria A, Sundstrom B, Meier S, Wiseley A. The myth of menstruation: how menstrual regulation and suppression impact contraceptive choice Women Health. 2019;125(1):125. https://doi.org/10.1186/s12905-019-0827-x.

14. Trego L. Development of the military Women's attitudes toward menstrual suppression scale: from construct definition to pilot testing. J Nurs Meas. 2009;17(1):45-72. https://doi.org/10.1891/1061-3749.17.1.45.

15. Trego L. Theoretical substruction: establishing links between theory and measurement of military women's attitudes towards menstrual suppression during military operations. J Adv Nurs. 2009;65(7):1548-59. https://doi.org/1 0.1111/j.1365-2648.2009.05010.x.

16. Trego L, Jordan P. Military women's attitudes toward menstruation and menstrual suppression in relation to the deployed environment: development and testing of the MWATMS-9 (short form). Womens Health Issues. 2010;20(4):287-93. https://doi.org/10.1016/j.whi.2010.03.002.

17. Cooper M. The pregnant traveler. Travel Med Infect Dis. 2006:4:196-201. https://doi.org/10.1016/j.tmaid.2005.06.003.

18. Hezelgrave N, Whitty C, Shennan A, Chappell L. Advising on travel during pregnancy. BMJ. 2011;342(apr28 1):d2506. https://doi.org/10.1136/ bmj.d2506.

19. Carroll I, van Gompel A. The pregnant wilderness traveler. Travel Med Infect Dis. 2005;3(4):225-38. https://doi.org/10.1016/j.tmaid.2004.11.004.

20. Anderson S. Advice for women travelers. In: Sanford C, Jong E, Pottinger $P$, editors. The travel and tropical medicine manual e-book: Elsevier Health Sciences; 2016. p. 192-214. Available at https://www.elsevier.com/books/ the-travel-and-tropical-medicine-manual/sanford/978-0-323-37506-1.

21. Salas R, Anderson S. Women in the wilderness. In: Auerbach P, editor Auerbach's wilderness medicine e-book: Elsevier's Health Sciences; 2016. p.
2117-49. Available at https://www.elsevier.com/books/auerbachswilderness-medicine-2-volume-set/auerbach/978-0-323-35942-9.

22. Nasser R, Rakedzon S, Dickstein $Y$, et al. Are all vaccines safe for the pregnant traveller? A systematic review and meta-analysis. J Travel Med. 2020;27:taz074. https://doi.org/10.1093/jtm/taz074.

23. Jaeger $V$, Tschudi $N$, Rüegg $R$, et al. The elderly, the young and the pregnant traveler - a retrospective data analysis from a large SwissTravelCenter with a special focus on malaria prophylaxis and yellow fever vaccination. Travel Med Infect Dis. 2015;6(6):475-84. https://doi.org/1 0.1016/j.tmaid.2015.10.001.

24. Schlagenhauf P, Grobusch M, Leder K, et al. Complex choices: which malaria chemoprophylaxis can be recommended for the pregnant traveller? Travel Med Infect Dis. 2019;32:101525. https://doi.org/10.1016/j.tmaid.2019.101525.

25. Cardona-Ospina J, Salazar-Vargas C, Rodríguez-Morales A, et al. Flying and pregnant? - regulations of the main airlines in Latin America. Travel Med Infect Dis. 2015;13(4):335-7. https://doi.org/10.1016/j.tmaid.2015.06.014.

26. Karsanji D, Bates $S$, Skeith $L$. The risk and prevention of venous thromboembolism in the pregnant traveller. J Travel Med. 2020;27:taz091. https://doi.org/10.1093/jtm/taz091.

27. Ben-Chetrit E, Lachish T, Mørch K, Atias D, Maguire C, Schwartz E. Schistosomiasis in pregnant travelers: a case series. J Travel Med. 2015;22(2): 94-8. https://doi.org/10.1111/jtm.12165.

28. Lau R, Chris R, Phuong M, et al. Treatment of soil-transmitted helminth infections in pregnancy: a systematic review and meta-analysis of maternal outcomes. J Travel Med. 2020;27:taz079. https://doi.org/10.1093/jtm/taz079.

29. Kim C, Chavez P, Pierce A, Murray A, Sander M, Kenyon C, et al. Rubella tracing associated with air travel. Travel Med Infect Dis. 2010;10(1):48-51. https://doi.org/10.1016/j.tmaid.2011.11.003.

30. Rodriguez-Morales A. Zika and microcephaly in Latin America: an emerging threat for pregnant travelers? Travel Med Infect Dis. 2016;22:75-6. https:// doi.org/10.1916/j.tmaid.2016.01.011

31. Alvarado-Arnez L, Escalera-Antezana J. Zika infection in pregnancy: follow up and outcomes, where are all the data? Travel Med Infect Dis. 2018;25:12. https://doi.org/10.1016/j.tmaid.2018.06.014.

32. Mohler S. Aging and space travel. Aerospace Med. 1962;33:594-7.

33. Palacios S, Comnalia J, Emsellem $C$, et al. Therapies for the management of genitourinary syndrome of menopause. Post Reprod Health. 2019: 2053369119866341. https://doi.org/10.1177/2053369119866341.

34. Bauer I. Australian senior adventure travellers to Peru: maximising older tourists' travel health experience. Travel Med Infect Dis. 2012;10(2):59-68. https://doi.org/10.1016/j.tmaid.2012.03.002.

35. Meldon S, Hargarten S. Airplane vacuum toilets: an uncommon travel hazard. J Travel Med. 1994;1(2):104-5. https://doi.org/10.1111/j.1708-8305.1 994.tb00570.x.

36. Handler C, Kopelman D, Hatou O. A case report of severe thrombosed hemorrhoids and rectal prolapse due to airplane toilet vacuum injury. World J Colorect Surg. 2013;3:18.

37. Bauer I. Contact lenses and travel: blessing or nightmare? Ann ACTM. 2011; 12:59-60.

38. Bauer I. Contact lens wearers' experiences while trekking in the Khumbu region/Nepal: a cross-sectional survey. Travel Med Infect Dis. 2015;13(2):17884. https://doi.org/10.1016/j.tmaid.2014.12.005

39. Chen $Y$, Bruning $E$, Rubino J, Eder S. Role of female intimate hygiene in vulvovaginal health: global hygiene practices and product usage. Women Health. 2017;13(3):58-67. https://doi.org/10.1177/1745505717731011.

40. Runeman B, Faergemann J, Larkö O. Experimental candida albicans lesions in healthy humans: dependence on skin pH. Acta Derm Venerol. 2000;80(6): 421-4. https://doi.org/10.1080/000155500300012819.

41. Runeman B, Rybo G, Larkö O, Faergemann J. The vulva skin microclimate: influence of panty liners on temperature, humidity and $\mathrm{pH}$. Acta Derm Venereol. 2003;83(2):88-92. https://doi.org/10.1080/00015550310007409.

42. Runeman B, Rybo G, Forsgren-Brusk U, Larkö O, Larsson P, Faergemann J. The vulvar skin microenvironment: influence of different panty liners on temperature, $\mathrm{pH}$ and microflora. Acta Derm Venerol. 2004;84(4):277-84. https://doi.org/10.1080/200484277284.

43. Sterry W, Schmoll M. Contact urticaria and dermatitis from self-adhesive pads. Contact Dermatitis. 1985;13(4):284-5. https://doi.org/10.1111/j.16000536.1985.tb02575.x.

44. Singh A, Kaur J. Occurrence of human urogenital myiasis due to neglected personal hygiene: a review. Trans R Soc Trop Med. 2019;113(1):1-4. https:// doi.org/10.1093/trstmh/try107. 
45. White G. Myasis. In: Cook G, editor. Manson's tropical diseases. 20th ed. London: WB Saunders; 1996. p. 1526-32.

46. Minton S, Bechtel B, Erickson T. Non-north American arthropod envenomation and parasitism. In: Auerbach P, editor. Wilderness medicine. 4th ed. St Louis: Mosby; 2001. p. 888-95.

47. Ritchie E. Issues for military women in deployment: an overview. Mil Med. 2001;166(12):1033-7. https://doi.org/10.1093/milmed/166.12.1033.

48. Hamill M. Climbing the seven summits: a comprehensive guide to the continents' highest peak. Seattle: The Mountaineers Book; 2012.

49. Wilson-Howarth J. How to shit around the worlds. The art of staying clean and healthy while traveling. San Francisco: Travelers' Tales; 2006.

50. Wardell D, Czerwinksi B. A military challenge to managing feminine and personal hygiene. J Am Acad Nurse Pract. 2005;13(4):187-93. https://doi. org/10.1111/j.1745-7599.2001.tb00245.x.

51. Zeller V, Didier B, Dos Santos G, et al. Upper urinary tract infection as a leading cause of fever among female travelers returning from the tropics. J Travel Med. 2003;10(2):139-40. https://doi.org/10.2310/7060.2003.31793.

52. Lowe N, Ryan-Wenger N. A clinical test of women's self-diagnosis of genitourinary infections. Clin Nurs Res. 2000;9(2):144-60. https://doi.org/1 $0.1177 / 105477380000900204$

53. Alves I, Reis N. Microfluidic smartphone quantitation of Escherichia coli in synthetic urine. Biosens Bioelectron. 2019;145:111624. https://doi.org/10.101 6/j.bios.2019.111624.

54. Grajewski B, Nguyen MM, Whelan EA, Cole RJ, Hein MJ. Measuring and identifying large-study metrics for circadian rhythm disruption in female flight attendants. Scand J Work Environ Health. 2003;29(5):337-46. https:// doi.org/10.5271/sjweh.740.

55. Radowicka M, Pietrzak B, Wielgoś M. Assessment of the occurrence of menstrual disorders in female flight attendants - preliminary report and literature review. Neuro Endocrinol Lett. 2013;34:809-13.

56. Boulware D. Gender differences among long-distance backpackers: a prospective study of women Appalachian Trail backpackers. Wild Environ Med. 2004;15(3): 175-80. https:/doi.org/10.1580/1080-6032(2004)15[175:GDALBA]2.0.CO;2.

57. Leutscher P, Nagley S. Health-related challenges in United States Peace Corps volunteers serving for two years in Madagascar. J Travel Med. 2003; 10:263-7. https://doi.org/10.2310/7060.2003.2690

58. McPherson M, Korfine L. Menstruation across time: menarche, menstrual attitudes, experiences, and behaviors. Womens Health Issues. 2004;14(6): 193-200. https://doi.org/10.1016/j.whi.2004.08.006.

59. Brooks-Gunn J, Ruble D. The menstrual attitude questionnaire. Psychosom Med. 1980;42(5):503-12. https://doi.org/10.1097/00006842-198009000-00005.

60. Davidson R. Tracks. London: Jonathan Cape; 1980.

61. Ishii S, Katagiri R, Kataoka T, Wada M, Imai S, Yamasaki K. Risk assessment study of dioxins in sanitary napkins produced in Japan. Regul Toxic Pharm. 2014;70(1):357-62. https://doi.org/10.1016/j.yrtph.2014.07.020.

62. Park M, Watanuki S. Unpleasantness and physiological responses in using sanitary napkins. J Physiol Anthropol Appl Hum Sci. 2005;24(1):7-14. https:// doi.org/10.2114/jpa.24.7.

63. Eason E, Feldman P. Contact dermatitis associated with the use of always sanitary napkins. Can Med Assoc J. 1996;154(8):1173-6.

64. Larsen W. Sanitary napkin dermatitis due to the perfume. Arch Dermatol. 1979;115(3):363. https://doi.org/10.1001/archderm.1979.04010030065027.

65. DeVito M, Schecter A. Exposure assessment to dioxins from the use of tampons and diapers. Environ Health Perspect. 2002;110(1):23-8. https://doi. org/10.1289/ehp.0211023.

66. Dixit S, Fischer G, Wittekind C. Recurrent menstrual toxic shock syndrome despite discontinuation of tampon use: is menstrual toxic shock syndrome really caused by tampons? Australas J Dermatol. 2013;54(4):283-6. https:// doi.org/10.1111/j.1440-0960.2012.00938.x.

67. Starr M. Smart Bluetooth menstrual cup tracks your period. https://www. cnet.com/news/smart-bluetooth-menstrual-cup-tracks-your-period/. Accessed 17 Sept 2010.

68. North B, Oldham M. Preclinical, clinical, and over-the-counter postmarketing experience with a new vaginal cup: menstrual collection. J Women's Health. 2011;20:303-11. https://doi.org/10.1089/jwh.2009.1929.

69. Van Eijk AM, Zulaika G, Lenchner M, et al. Menstrual cup use, leakage, acceptability, safety, and availability: a systematic review and meta-analysis. Lancet Public Health. 2019;4(8):e376-93. https://doi.org/10.1016/S2468-2 667(19)30111-2.

70. Day S. A retained menstrual cup. Int J STD AIDS. 2012;23(5):367-8. https:// doi.org/10.1258/ijsa.2011.011277.
71. Czerwinski B, Wardell D, Yoder $L$, et al. Variations in feminine hygiene practices of military women in deployed and noncombat environments. Mil Med. 2001;166(2):152-8. https://doi.org/10.1093/milmed/166.2.152.

72. Gillis E. Woman searched at airport when feminine hygiene product alerts scanner, 2017. https://www.wsoctv.com/news/local/women-searched-at-airport-a fter-feminine-hygiene-product-alerts-scanner/541755851/. Accessed 13 Feb 2020.

73. Mama Instincts. The TSA full body scanner CAN see your menstrual cup here's what you need to know. https://mamainstincts.com/scanner-can-seemenstrual-cup/. Accessed 13 Feb 2020.

74. Cushing B. Reponses of polar bears to human menstrual odors. Int Conf Bear Res Manage. 1983;5:270-4.

75. Bauer I. Relationships between female tourists and male locals in Cuzco/ Peru: implications for travel health education. Travel Med Infect Dis. 2009; 7(6):350-8. https://doi.org/10.1016/j.tmaid.2009.09.002.

76. Berger D, Eames D, Prados-Ruano P. Mental health care of Western expatriates in Tokyo. Travel Med Infect Dis. 2008;6(5):321-5. https://doi.org/1 0.1016/j.tmaid.2008.04.004

77. Bauer I. Itchy critters: preparing volunteer travellers for head lice infestation. Travel Med Infect Dis. 2019;32:101455. https://doi.org/10.1016/.t.tmaid.2019.07.011.

78. Lankester T. Health care of the long-term travellers. Travel Med Infect Dis. 2005;3(3):143-55. https://doi.org/10.1016/j.tmaid.2004.09.002.

79. Lopes Cardozo B, Gotway Crawford C, Eriksson C, et al. Psychological distress, depression, anxiety, and burnout among international humanitarian aid workers: a longitudinal study. PLoS One. 2012;7:e44948. https://doi.org/1 0.1371/journal.pone.0044948.

80. Bor R. Psychological factors in airline passenger and crew behaviour: a clinical overview. Travel Med Infect Dis. 2007;5(4):207-16. https://doi.org/1 0.1016/j.tmaid.2007.03.003

81. Oakes M, Bor R. The psychology of fear of flying (part I): a critical evaluation of current perspectives on the nature, prevalence and etiology of fear of flying. Travel Med Infect Dis. 2010;8(6):327-38. https://doi.org/10.1016/j.tma id.2010.10.001

82. Oakes M, Bor R. The psychology of fear of flying (part II): a critical evaluation of current perspectives on approaches to treatment. Travel Med Infect Dis. 2010;8(6):339-63. https://doi.org/10.1016/j.tmaid.2010.10.002.

83. Bauer I. When travel is a challenge: travel medicine and the 'dis-abled' traveler. Travel Med Infect Dis. 2018;22:66-72. https://doi.org/10.1016/j.tma id.2018.02.001.

84. Felkai P, Marcolongo T, Van Aswegen M. Stranded abroad: a travel medicine approach to psychiatric repatriation. J Travel Med. 2020;27:taaa013. https:// doi.org/10.1093/jtm/taaa013.

85. Mirehie M, Gibson $\mathrm{H}$. The relationship between female snow-sport tourists' travel behaviors and well-being. Tour Manag Perspect. 2020;33:100613. https://doi.org/10.1016/j.tmp.2019.100613.

86. Levenson M. Risk taking and personality. J Pers Soc Psychol. 1990;58(6): 1073-80. https://doi.org/10.1037/0022-3514.58.6.1073.

87. Reisinger Y, Mavondo F. Travel anxiety and intentions to travel internationally: implications of travel risk perception. J Travel Res. 2005;43(3): 212-25. https://doi.org/10.1177/0047287504272017.

88. Reisinger $Y$, Mavondo F. Cultural differences in travel risk perception. J Travel Tour Mark. 2006;20(1):13-31. https://doi.org/10.1300/J073v20n01_02.

89. Reisinger $Y$, Crotts J. The influence of gender on travel risk perceptions, safety, and travel intentions. Tour Anal. 2009;14(6):793-807. https://doi.org/1 $0.3727 / 108354210 \times 12645141401269$.

90. AlSaleh D, Moufakkir O. An exploratory study of the experience of VFR tourists: a culture shock perspective. Tour Geogr. 2019;21(4):565-85. https:// doi.org/10.1080/14616688.2018.1545251.

91. Moufakkir O. Experience of Arab/Muslim women visiting relatives in the west and the management of stigma by association. Tour Manag. 2020;78: 104073. https://doi.org/10.1016/j.tourman.2019.104073.

92. Moufakkir O. The stigmatized tourist. Ann Tour Res. 2015;53:17-30. https:// doi.org/10.1016/j/annals.2015.04.004.

93. Choovichian V, Chatapat L, Piyaphanee W. A bubble turtle: bullous contact dermatitis after a black henna tattoo in a backpacker in Thailand. J Travel Med. 2015;22(4):287-8. https://doi.org/10.1111/jtm.12202.

94. DeMaria A, Flores M, Hirth J, Rerenson A. Complications related to pubic hair removal. Am J Obstet Gynecol. 2014;210:528.e1-5. https://doi.org/10.1 016/j.ajog.2014.01.036.

95. Desruelles F, Cunningham S, Dubois D. Pubic hair removal: a risk factor for 'minor' STI such as molluscum contagiosum? Sex Transm Infect. 2013;89(3): 216. https://doi.org/10.1136/sextrans-2012-050982. 
96. Baxi L, Dziadosz M. Complications following "Brazilian" waxing for pubic hair removal. Am J Obstet Gynecol. 2014;211(6):713-4. https://doi.org/10.1016/j.a jog.2014.07.063.

97. Osterberg E, Gaither T, Awad M, et al. Correlation between pubic hair grooming and STIs: results from a nationally representative probability sample. Sex Transm Infect. 2017;93(3):162-6. https://doi.org/10.1136/sextra ns-2016-052687.

98. Veraldi S, Schianchi R, Ramoni S, Nazzaro G. Pubic hair removal and Phthirus pubis infestation. Int J STD AIDS. 2018;29(1):103-4. https://doi.org/10.1177/ 0956462417740292.

99. Bauer I. Ayahuasca: a risk for travellers? Travel Med Infect Dis. 2018;21:74-6. https://doi.org/10.1016/j.tmaid.2018.01.002

100. Callaghan M. A drink to die for: arak and methanol poisoning in Indonesia Travel Med Infect Dis. 2015;13(6):507-8. https://doi.org/10.1016/j.tmaid.201 5.11.001.

101. Brown $L$, de Coteau D, Lavrushkina N. Taking a walk: the female tourist experience. Tour Stud. 2020;20(3):1-17. https://doi.org/10.1177/146879762 0930036.

102. Robinson J. Wayward women. Oxford: Oxford University Press; 1990.

103. Barton A. 'Wayward girls and wicked women': two centuries of 'semi-penal' control. Liverpool Law Rev. 2000;22(2/3):157-71. https://doi.org/10.1023/A:1 010652521379

104. Weatherby T, Vidon E. Delegitimizing wilderness as the man cave: the role of social media in female wilderness empowerment. Tour Stud. 2018;18(3): 332-52. https://doi.org/10.1177/1468797618771691.

105. Heimtun B, Abelsen B. Singles and solo travel: gender and type of holiday. Tour Cult Comm. 2013;13(3):161-74. https://doi.org/10.3727/109830414X13 911221027443.

106. Wilson E, Little D. The solo female travel experience: exploring the 'geography of women's fear'. Curr Issue Tour. 2008;11(2):167-86. https://doi. org/10.2167/cit342.0

107. Osman $H$, Brown $L$, Phung T. The travel motivations and experiences of female Vietnamese solo travelers. Tour Stud. 2019;20(2):248-67. https://doi. org/10.1177/1468797619878307.

108. Yang E, Khoo-Lattimore C, Arcodia C. Power and empowerment: how Asian solo female travellers perceive and negotiate risks. Tour Manag. 2018;68:3245. https://doi.org/10.1016/j.tourman.2018.02.017.

109. Seow D, Brown L. The solo female Asian tourist. Curr Issue Tour. 2018;21(1): 1187-206. https://doi.org/10.1093/trstmh/try107.

110. Khan M, Chelliah S, Ahmed S. Intention to visit India among potential travellers: role of travel motivation, perceived travel risks, and travel constraints. Tour Hosp Res. 2019;12(3):351-67. https://doi.org/10.1177/14673 58417751025

111. Thomas T, Mura P. The 'normality of unsafety'- foreign solo female travellers in India. Tour Recreat Res. 2019;44(1):33-40. https://doi.org/10.1080/025082 81.2018.1494872.

112. Abrahams N, Devries K, Watts C, Pallitto C, Petzold M, Shamu S, et al. Worldwide prevalence of non-partner sexual violence: a systematic review. Lancet. 2014; 383(9929):1648-54. https://doi.org/10.1016/S0140-6736(13)62243-6.

113. Calafat A, Hughes K, Blay N, Bellis MA, Mendes F, Juan M, et al. Sexual harassment among young tourists visiting Mediterranean resorts. Arch Sex Behav. 2013;42(4):603-12. https://doi.org/10.1007/s10508-012-9979-6.

114. Deliv C, Flaherty G. Risk of in-flight sexual assaults: time to wake up? J Travel Med. 2020:taaa026. https://doi.org/10.1093/jtm/taaa026.

115. Tardivo S, Zenere A, Moretti F, Marchiori F, Berti D, Migliorini M, et al. The Traveller's Risk Perception (TRiP) questionnaire: pre-travel assessment and post-travel changes. Int Health. 2020;12(2):116-24. https://doi.org/10.1093/ inthealth/ihz033.

116. Farnham A, Ziegler S, Blanke U, et al. Does the DOSPERT scale predict risktaking behaviour during travel? A study using smartphones. J Travel Med. 2018;25:tay064. https://doi.org/10.1093/jtm/tay064.

117. Sorell T, Whitty M. Online romance scams and victimhood. Security J. 2019; 32(3):342-61. https://doi.org/10.1057/s41284-019-00166-w.

118. Whitty M. Anatomy of the online dating romance scam. Security J. 2015 ; 28(4):443-55. https://doi.org/10.1057/sj.2012.57

119. Whitty M, Buchanan T. The online dating romance scam: the psychological impact on victims - both financial and non-financial. Criminol Crim Just. 2015;16(2):1-9. https://doi.org/10.1177/1748895815603773.

120. Buś M, Schellberg T, Budowle B. Human trafficking - multinational challenge for forensic science. Forensic Sci Int-Gen. 2019;7(1):403-5. https:// doi.org/10.1016/j.fsigss.2019.10.029.
121. Scannell M, MacDonald A, Berger A, Boyer N. Human trafficking: how nurses can make a difference. J Forensic Nurs. 2018;14(2):117021-121. https://doi. org/10.1097/JFN.0000000000000203.

122. Hernandez D, Rudolph A. Modern day slavery: what drives human trafficking in Europe? Eur J Polit Econ. 2015;38:118-39. https://doi.org/10.101 6/j.ejpoleco.2015.02.002.

123. McCauley M, van den Broek N. Challenges in the eradication of female genital mutilation/cutting. Int Health. 2019;11(1):1-4. https://doi.org/10.1186/ s12936-018-2570-4.

124. Plugge E, Adam S, El Hindi L, et al. The prevention of female genital mutilation in England: what can be done? J Public Health. 2019;41(3):e261-6. https://doi.org/10.1093/pubmed/fdy128.

125. Tantet $C$, Aupiais $C$, Bourdon M, Sorge F, Pagès A, Levy D, et al. Female genital mutilation: an evaluation of the knowledge of French general and specialized travel medicine practitioners. J Travel Med. 2018;25(1):1-3. https://doi.org/10.1093/jtm/tax090.

126. Chiodini J. Female genital mutilation, "vacation cutting" and the travel medicine consultation. Travel Med Infect Dis. 2017;18:87-91. https://doi. org/10.1016/j.tmaid.2017.08.007.

127. RCPSG. Travel Medicine Updates: Ten years gone, and female genital mutilation. https://rcpsg.ac.uk/elearning/product/ten-years-gone-and-fema le-genital-mutilation. Accessed 3.5.2020.

128. Heywood A, Forssman B, Seale $H$, et al. General practitioners' perception of risk for travelers visiting friends and relatives. J Travel Med. 2015;22(6):36874. https://doi.org/10.1111/jtm.12229.

129. United Nations. Sustainable development goals. 2015. https://sustaina bledevelopment.un.org/?menu=1300. Accessed 6.2.2019.

130. United Nations. The Sustainable Development Goals Report 2019. New York: United Nations. https://unstats.un.org/sdgs/report/2019/The-SustainableDevelopment-Goals-Report-2019.pdf. Accessed 13 Nov 2019.

131. Bauer I. Improving global health - is tourism's role in poverty elimination perpetuating poverty, powerlessness and 'ill-being'? Glob Public Health. 2017;12(1):45-64. https://doi.org/10.1080/17441692.2015.1094109.

132. One Health Initiative. (n.d.).Retrieved from http://www.onehealthinitiative. com/mission.php. Accessed 3 Mar 2020.

133. Bauer I. The plight of the cute little lambs: travel medicine's role in animal welfare. J Ecotour. 2017;16(2):95-111. https://doi.org/10.1080/14724049.201 6.1206551.

134. Bauer I. The health impact of tourism on local and indigenous populations in resource-poor countries. Travel Med Infect Dis. 2008;6(5):276-91. https:// doi.org/10.1016/j.tmaid.2008.05.005.

135. Amaro S, Morgado Ferreira B, Henriques C. Towards a deeper understanding of the purchase of souvenirs. Tour Hosp Res. 2019;20(2):22336. https://doi.org/10.1177/1467358419848139.

136. Alrwajfah M, Almeida-García F, Cortés-Macías R. Females' perspectives on tourism's impact and their employment in the sector: the case of Petra, Jordan. Tour Manag. 2020;78:104069. https://doi.org/10.1016/j.tourman.201 9.104069.

137. Hillman W. 'Risky business': the future for female trekking guides in Nepal. Tour Hosp Res. 2019;19(4):397-407. https://doi.org/10.1177/146735841 8768661.

138. Fan D, Zhang H, Jenkins C, Lin P. Does social contact lessen perceived cultural distance? Evidence from tourist-host social contact. Ann Tour Res. 2016;61:223-5. https://doi.org/10.1016/j.annals.2016.08.002.

139. Traugott $M$, Singh $M$, Raj $D$, Kutalek R. Geophagy in India: a qualitative exploratory study on motivation and perception of female consumers. Trans R Soc Trop Med Hyg. 2018;113(3):123-30. https://doi.org/10.1093/ trstmh/try123.

140. Bauer I. 'They don't just come for Machu Picchu': Iocals' views of touristlocal sexual relationships in Cuzco, Peru. Cult Health Sex. 2008;10(6):611-24. https://doi.org/10.1080/13691050802155376.

141. Bauer I. Inca Trail porters: the health of local tourism employees as a challenge for travel medicine. J Travel Med. 2003;10(2):94-9. https://doi. org/10.2310/7060.2003.31654.

142. Malm S. Youths are boiling sanitary pads to get high in Indonesia... creating hallucinogenic drink that makes them feel as if they are flying, officials warn Some Indonesian teens are drinking water boiled with used menstrual pads to get high - here's what it does to the body. 2018. https://www.dailymail.co.uk/news/article-6388633/ Indonesian-teenagers-boiling-sanitary-pads-high-officials-warn.html. Accessed 10 Nov 2020. 
143. Webster E. Teenagers in Indonesia are reportedly boiling menstrual pads to get high. 2018. https://www.teenvogue.com/story/teenagers-in-indonesia-a re-reportedly-boiling-menstrual-pads-to-get-high. Accessed 13 Nov 2020.

144. Hennegan J. Inserting informed choice into global menstrual product use and provision. Lancet Public Health. 2019;4(8):e361-2. https://doi.org/10.101 6/S2468-2667(19)30126-4.

145. Sommer M, Hirsch J, Nathanson C, Parker R. Comfortably, safely, and without shame: defining menstrual hygiene management as a public health issue. Am J Public Health. 2015;105(7):1302-11. https://doi.org/10.2105/A JPH.2014.302525.

146. 28 May - Menstrual Hygiene Day https://menstrualhygieneday.org/. Accessed 31 May 2020.

147. Mehta S, Grover A, Mittal N, Nanda P, Khatuja R, et al. Reusable sanitary napkins - time to revisit. J Public Health. 2020;fdaa192:1-7. https://doi.org/1 0.1093/pubmed/fdaa192.

148. Zamani-Farahani H, Henderson J. Islamic tourism and managing tourism development in Islamic societies: the cases of Iran and Saudi Arabia. Int J Tour Res. 2010;12:79-89. https://doi.org/10.1002/jtr.741.

149. Sobhy Temerak M. Bikini or burkini? The role of swimwear and age as determinants of beach interaction with others. Tour Manag. 2019;75:269-83. https://doi.org/10.1016/j.tourman.2019.05.010.

150. Brown $\mathrm{L}$, Osman $\mathrm{H}$. The female tourist experience in Egypt as an Islamic destination. Ann Tour Res. 2017;63:12-22. https://doi.org/10.1016/j.annals.2 016.12.005.

151. Bauer I. Educational issues and concerns in travel health advice: is all the effort a waste of time? J Travel Med. 2005;12(1):45-52. https://doi.org/10.231 0/7060.2005.00008

152. Brown R, Maslen H, Savulescu J. Responsibility, prudence and health promotion. J Public Health (Oxf). 2019;41(3):561-5. https://doi.org/10.1093/ pubmed/fdy 113 .

153. Passafaro P. Attitudes and tourists' sustainable behavior: an overview of the literature and discussion of some theoretical and methodological issues. J Travel Res. 2019;59(4):579-601. https://doi.org/10.1177/0047287519851171.

154. León C, Araña J. Tourist sustainable behaviour and personal communication. Ann Tour Res. 2020:102897. https://doi.org/10.1016/j.annals.2020.102897.

155. Han H, Hyun S. What influences water conservation and towel reuse practices of hotel guests? Tour Manag. 2018;64:67097. https://doi.org/10.101 6/j.tourman.2017.08.005.

156. Bauer I. Looking over the fence - how travel medicine can benefit from tourism research. J Travel Med. 2015;22:206-7. https://doi.org/10.1111/ jtm.12197.

157. Farnham A, Blanke $U$, Stone $E$, et al. Travel medicine and mHealth technology: a study using smartphones to collect health data during travel. J Travel Med. 2016;23:taw056. https://doi.org/10.1093/jtm/taw056.

158. Baroutsou V, Hatz C, Blanke U, Haile S, Fehr J, Neumayr A, et al. TOURIST2 Tracking of urgent risks in Swiss travellers to the 6 main travel destinations - feasibility and ethical considerations of a smartphone application-based study. Travel Med Infect Dis. 2020;39:101912. https://doi.org/10.1016/j.tma id.2020.101912.

\section{Publisher's Note}

Springer Nature remains neutral with regard to jurisdictional claims in published maps and institutional affiliations.

Ready to submit your research? Choose BMC and benefit from:

- fast, convenient online submission

- thorough peer review by experienced researchers in your field

- rapid publication on acceptance

- support for research data, including large and complex data types

- gold Open Access which fosters wider collaboration and increased citations

- maximum visibility for your research: over $100 \mathrm{M}$ website views per year

At BMC, research is always in progress.

Learn more biomedcentral.com/submissions 